\title{
Isolation and Evaluation of Multi-Trait Novel Bacterial Endophytes from Root Nodules of Mungbean (Vigna radiata)
}

\author{
Rekha Sansanwal*, Umang Ahlawat, Priyanka Batra and Leela Wati \\ Department of Microbiology, CCS HAU, Hisar, Haryana, India \\ *Corresponding author
}

\section{A B S T R A C T}

Keywords

Mungbean,

Endophytes, Plant

growth promotion

traits

Article Info

Accepted:

20 February 2018

Available Online:

10 March 2018
The mungbean is one of the most important pulse crop cultivated in India, despite variation in salinity, temperature, and waterlogging conditions in different agro-climatic zones. Bacterial endophytes are endosymbiotic in nature and employ advantageous effects on host plant. In the present study, a total 41 endophytes were isolated from Mungbean nodule from the field during summer and kharif season. Among all isolates, $46 \%$ of the isolates were tolerating temperature up to $45^{\circ} \mathrm{C}$ while and $19 \%$ could tolerate salinity up to $5 \%$ $\mathrm{NaCl}$ concentration. The majority of endophytes were found to be producers of indole acetic acid and ammonia which varied in the range of $1.12-44.88 \mu \mathrm{g} / \mathrm{ml}$ and $0-3.47 \mu \mathrm{g} / \mathrm{ml}$, respectively. P-solubilization activity was shown by 41 isolates on solid medium (49\%), 1 aminocyclopropane-1-carboxylate utilization (24\%), siderophores (29\%), and $\mathrm{HCN}$ production $(76 \%)$. The isolates were having multiple growth traits along with resistance to varying temperatures and salinity conditions thus qualifying as potential candidates for desired yield in fields.

\section{Introduction}

The mungbean is third most important pulse crop of India after chickpea and pigeon pea with India being the largest producer $(>50 \%$ of total production) in world (Singh and Singh, 2011).

It belongs to the Papilionoideae family, order Leguminosae and botanically recognized as Vigna radiata (L.). It is rich in proteins, minerals, and vitamins (Watanabe et al., 2017). Even though holding such a great promise, mungbean is often grown in marginal lands with limited inputs making it prone to a number of abiotic and biotic stresses causing tremendous yield losses. The crop is not tolerant to subsoil salinity, which can restrict root growth and reduce the plant's ability to extract moisture and nutrients from the soil (Farooq et al., 2017). Climatic conditions like high temperature during summer and water logging in rainy season also greatly affect the crop (Chaudhari et al., 2017).

There are two possible ways to overcome the above-mentioned problems, either development of the genetically modified plants or application of bacterial endophytes (Zhu et al., 2018; Fuganti-Pagliarini et al., 2017; Roy et al., 2014). There are serious conflicts against usage of genetically modified 
plants in worldwide due to various reasonsviz. development of superweeds in nature, rise in allergies and multidrug resistance (Selb et al., 2017; Arpaia et al., 2017). However, application of beneficial endophytes to plants may furnish the soil with valuable microbes thus resulting in the healthier environment for plant growth (Chen et al., 2018). Plant growth promoting bacterial endophytes (PGPBEs) are a heterogeneous group of bacteria that can be found in the rhizosphere, at root surfaces and in association with roots (Ahmad et al., 2008) and without showing any negative effect on their host (Dudeja et al., 2012). Endophytic bacteria (non-rhizobia) can be used as biofertilizers and are believed to promote plant growth both indirectly as well as directly. Indirectly these bacteria help plants to acquire nutrients via nitrogen fixation, phosphate solubilization activity, production of siderophores or by establishing the plant systemic resistance.

They benefit directly by producing phytohormones such as auxins or cytokinins or by producing the enzyme 1aminocyclopropane-1-carboxylate deaminase (ACC) which lowers plant ethylene levels or by supplying essential vitamins to plants (Walkelin et al., 2004). These organisms can also increase plant tolerance to waterlogging, salt stress and drought (Grichko and Glick, 2001; Mayak et al., 2004). Bacterial endophytes can act as biocontrol agents through antibiotic production and lytic enzyme production, e.g. hydrolases, chitinases, laminarinases, and glucanases (Chernin and Chet, 2002; Ezra et al., 2004). Moreover, endophytes have also been reported to trigger ISR (induced systemic resistance) based plant growth promotion (Barka et al., 2002).

The information is scanty regarding isolation of native root endogenous endophytes, their role in phosphorus bioavailability, growth promotion and interaction with rhizobia in mungbean. This study was undertaken to identify major culturable endophytic bacteria and to evaluate their plant growth promoting traits from root nodules of mungbean.

\section{Experimental procedures}

\section{Collection and isolation of endophytic bacteria}

For the isolation of bacterial endophytes, the nodules were collected from the roots of mungbean grown in Chaudhary Charan Singh Haryana Agricultural university farms, Hisar, Haryana, India during summer and kharif seasons. Nodules were surface-sterilized using $70 \%$ ethanol and $0.1 \% \mathrm{HgCl}_{2}$ and repeatedly washed with sterile water. Nodules were crushed in the sterile conditions in petri dish with the help of glass rod in autoclaved distilled water and the resulting suspension was streaked on Tryptone soy agar (TSA) plates followed by incubation in Biological oxygen demand (BOD) incubator at $30^{\circ} \mathrm{C}$. After 24-36 h, the colonies were picked and purified by single colony streaking on the TSA plates and maintained at $4^{\circ} \mathrm{C}$.

Assessment of endophytic isolates for growth at salt and temperature tolerance

All endophytic bacterial isolates were checked for their ability to grow at different concentrations of salt $(\mathrm{NaCl})$ i.e., 1, 2, 3, 4 and $5 \%(\mathrm{w} / \mathrm{v})$ and at different temperatures i.e., $28 \pm 2^{\circ} \mathrm{C}, 35 \pm 2^{\circ} \mathrm{C}, 40 \pm 2^{\circ} \mathrm{C}$, on TSA medium containing $20 \quad \mathrm{mM}$ HEPES (N-2hydroxyethane-sulphonic acid) (Marsudi et al., 1999). The plates containing $30 \mathrm{ml}$ of the medium were spotted with a loopful of the bacterial isolate. The plates were incubated for 3-4 days at $30^{\circ} \mathrm{C}$ in BOD incubator. The susceptibility of bacterial isolates to tolerate salt was recorded as a positive or negative result. 
Evaluation of bacterial endophytes for Plant Growth Promoting (PGP) Traits

All the endophytes were screened for the presence of beneficial characters like IAA, phosphate solubilization, siderophore production, ACC utilization, hydrogen cyanide $(\mathrm{HCN})$ production, ammonia excretion.

Indole acetic acid was determined in the culture supernatant by adding Salkowski reagent (Gordon and Weber, 1951). Indole acetic acid different concentrations (10-100 $\mu \mathrm{g}$ $\mathrm{ml}^{-1}$ ) were used as a standard and results were expressed as $\mu \mathrm{g}$ IAA produced $\mathrm{ml}^{-1}$ of culture supernatant. Phosphate solubilization ability of the endophytes was determined by spotting the cultures on Pikovskaya's agar plates (Pikovskya, 1948). The phosphorous solubilization index (P-SI) respective bacteria were calculated according to Edi Premono et al., (1996). All the endophytic bacterial isolates were screened for siderophore production activity using universal chemical assay of Schwyn and Neilands (1987) on Chrome azurol S (CAS) agar plates.

The presence of iron chelator (siderophore) was indicated by the decolorization of the blue-colored ferric dye complex, resulting in yellow-orange halo zones around the colonies. $\mathrm{HCN}$ production by the bacterial isolates was determined qualitatively by the method of Alstrom and Burns (1989). The change in the color of the strips from yellow to orange-red was observed for hydrogen cyanide production. The estimation of ACC utilization was done by standard protocol given by Penrose and Glick (2003) using the minimal medium (supplemented with $3 \mathrm{mM}$ ACC. For ammonia production, the isolate was grown in $5 \mathrm{ml}$ peptone medium at $30^{\circ} \mathrm{C}$ for $96 \mathrm{~h}$. After the bacterial growth, Nessler's reagent was added to the bacterial culture in 2:1 ratio and observed for the development of brown to yellow color (Cappuccino and Sherman, 1992). Uninoculated culture medium was treated as the control.

\section{Results and Discussion}

A total of forty-one bacterial endophytic isolates were obtained from healthy nodules of mungbean plant roots. The bacterial colonies of different morphology were observed such as raised, rough, creamish, whitish, and gummy. All the 41 isolates were screened for assessment at different temperatures $\left(30-45^{\circ} \mathrm{C}\right)$ conditions and salt concentrations (1-5\%). At 30 and $35^{\circ} \mathrm{C}$, all the forty-one endophytic isolates showed growth while 39 isolates showed growth at $40^{\circ} \mathrm{C}$ and only 19 isolates showed growth at $45^{\circ} \mathrm{C}$. All the 41 endophytic isolates from nodules of mungbean showed growth at $1 \%$ salt concentration. At 2, 3, 4 and $5 \%$ salt concentration $27,22,16$ and 11 isolates were showing growth, respectively.

All the endophytic isolates from mungbean nodules were screened for IAA production and $76 \%$ of the isolates were found positive and were producing IAA in the range of 01.12$44.88 \mu \mathrm{g} / \mathrm{ml}$. Highest IAA production was shown by isolate E13 $(44.88 \mu \mathrm{g} / \mathrm{ml})$ followed by isolate E14 $(39.52 \mu \mathrm{g} / \mathrm{ml})$. Among all the endophytic isolates only 20 isolates showed the P-SI of more than 0.7. Maximum P-SI was observed in E13 (4.4) followed by E17 (3.8), E6 (3.6) and E14 (3.5). Out of 41 isolates, only twelve cultures were found positive for siderophore production and 12 bacterial isolates showed $\mathrm{HCN}$ production. Overall, $76 \%$ endophytic isolates showed ACC utilization ability. On plates having ammonium sulfate, $51 \%$ of the endophytic isolates showed significant growth, $27 \%$ of the isolates had moderate growth while, $2 \%$ showed little growth. Most of the isolates were also able to excrete ammonia, which varied from 0.25 to $3.47 \mu \mathrm{g} / \mathrm{ml}$ in liquid medium after 4 days of incubation. 
Table.1 Screening of multi-trait nodule endophytic bacterial isolates

\begin{tabular}{|c|c|c|c|c|c|c|c|c|c|}
\hline $\begin{array}{l}\text { Sr. } \\
\text { No. }\end{array}$ & $\begin{array}{l}\text { Endop } \\
\text { hytic } \\
\text { isolate }\end{array}$ & $\begin{array}{l}\text { Temp. } \\
\text { toleran } \\
\text { ce } \\
\text { (upto } \\
\left.45^{0} \mathrm{C}\right)\end{array}$ & $\begin{array}{l}\text { Salt } \\
\text { toleran } \\
\text { ce } \\
\text { (upto } \\
5 \% \text { ) }\end{array}$ & $\begin{array}{l}\text { IAA } \\
\text { produ } \\
\text { ction } \\
(\mu \mathrm{g} / \mathrm{m} \\
\text { l) }\end{array}$ & $\begin{array}{l}\text { P- } \\
\text { SI }\end{array}$ & $\begin{array}{l}\text { Sider } \\
\text { opho } \\
\text { re } \\
\text { prod } \\
\text { uctio } \\
\text { n }\end{array}$ & $\begin{array}{l}\text { HCN } \\
\text { product } \\
\text { ion }\end{array}$ & $\begin{array}{l}\text { ACC } \\
\text { utilizatio } \\
\text { n }\end{array}$ & $\begin{array}{l}\text { Ammonia } \\
\text { excretion } \\
(\mu \mathrm{g} / \mathrm{ml})\end{array}$ \\
\hline 1 & E6 & + & + & 23.58 & 3.6 & + & + & +++ & 2.08 \\
\hline 2 & E13 & + & + & 44.88 & 4.4 & + & + & +++ & 2.98 \\
\hline 3 & E14 & + & + & 39.52 & 3.5 & + & + & +++ & 3.17 \\
\hline 4 & E17 & + & + & 29.60 & 3.8 & - & + & +++ & 3.47 \\
\hline
\end{tabular}

The data reckoned that maximum ammonia excretion was shown by isolate E17 $(3.47 \mu \mathrm{g} / \mathrm{ml})$ followed by isolate E14 (3.17 $\mu \mathrm{g} / \mathrm{ml})$. On the basis of different plant growth promoting traits viz. IAA production, phosphate solubilization, siderophore production, potassium solubilization, $\mathrm{HCN}$ production, ACC utilization and ammonia excretion, four endophytes possessed multiple beneficial plant growth promoting traits (Table 1).

Endophytic bacterial isolates were isolated from mungbean nodules using tryptone soya agar medium (Gtari et al., 2104; Rajendran et al., 2011). In the present study, $46 \%$ endophytic isolates were able to grow at $45^{\circ} \mathrm{C}$ which was comparatively higher than the previous reports (Bansal et al., 2014; Rashid et al., 2012). Further, a total of $26 \%$ of the bacterial endophytes showed growth at $5 \%$ $\mathrm{NaCl}$ concentration and these results were in consonance with those of Arora et al., (2014). These outcomes suggest that isolates in present study can tolerate the variation in salinity and temperature and thus can give high competitive value in the rhizosphere to survive in harsh environmental conditions in the soil.

Out of 41 isolates in this study, 31 bacterial endophytic isolates showed the ability to produce IAA and maximum was produced by
E13 $(44.88 \mu \mathrm{g} / \mathrm{ml})$ compared to that reported by Perez-Rosales et al., (2017) and Li et al., (2008). IAA induces physiological activities such as plant cell division and root initiation (Panchal and Ingle, 2011). This study revealed that $49 \%$ of strains showed phosphate solubilization on Pikovskaya medium and similar findings were recorded by Narula et al., (2013) and Saini et al., (2015).

From these reports it is observed that endophytic bacteria of root zone increase the phosphorus content in the soil, which assists in increasing vegetation and improve the plant growth. Production of siderophore and $\mathrm{HCN}$ by ten and twelve isolates, respectively shows presence of important traits in terms of protection of plant from pathogens and as per earlier reports (Rajkumar et al., 2010), they can be an eco-friendly and excellent replacement for weedicides, fungicides, and nematicides.

Presence of siderophores and $\mathrm{HCN}$ has also been reported by Matsuoka et al., (2013) and Egamberdieva et al., (2017). ACC utilization ability shown by $76 \%$ isolates correlates with earlier reports of Singh and Jha (2015) and Cheng et al., (2007) which showed that inoculation with ACC deaminase producing strains can stimulate the growth of the host plant. It has been assumed that inoculation 
with NH3 excreting bacteria may enhance the plant growth as a result of their ability to fix nitrogen (N2) to ammonia (NH3) making it an available nutrient for plant growth (Ngoma et al., 2014) and in this study also maximum number of endophytic isolates were excreting ammonia.

In the present study, four endophytic isolates namely E6, E13, E14 and E14were selected on the basis of multiple growth-promoting traits as they were able to induce IAA production, $\mathrm{P}$ solubilization, ammonia excretion and were also having antagonistic activities such HCN production, siderophore production and ACC deaminase activity which are essential traits for the promotion of plant protection from various biological diseases.

The most important character of these isolates which generates novelty in their nature is that they can tolerate variations of temperature and salinity and help in countries like India, where there is huge biodiversity amongst various agro-climatic zones. In the light of above, it may be concluded that these endophytic isolates can be used for growth promotion of mungbean under pothouse and field conditions.

\section{References}

Ahmad, P., and Sharma, S. (2008) Salt Stress and Phyto-Biochemical Responses of Plants. Plant Soil Environ.54: 89-99.

Alstrom, S., and Burns, R.G. (1989) Cyanide production by rhizobacteria as a possible mechanism of plant growth inhibition. BiolFert Soils. 7:232-238.

Arora, S., Patel, P.N., Vanza, M.J., and Rao, G.G. (2014) Isolation and characterization of endophytic bacteria colonizing halophyte and other salt-tolerant plant species from coastal Gujrat.Afr. J. Microbiol. Res., 8:1779-1788.
Arpaia, S., Birch, A.N.E., Kiss, J., van Loon, J.J., Messéan, A., Nuti, M., and Tebbe, C.C. (2017) Assessing environmental impacts of genetically modified plants on non-target organisms: The relevance of in planta studies. Sci Total Environ. 583: 123-132.

Bansal, M., Kukreja, K., Suneja, S., and Dudeja, S.S. (2014) Symbiotic effectivity of high-temperature tolerant mungbean (Vigna radiata) rhizobia under different temperature conditions. Int $\mathbf{J}$ Curr. Microbiol. Appl. Sci. 3:807-821.

Barka, E.A., Gognies, S., Nowak, J., Audran, J.C., and Belarbi, A. (2002) Inhibitory effect of endophyte bacteria on Botrytis cinerea and its influence to promote the grapevine growth. Biol Control.24: 135142.

Cappuccino, J.C. and Sherman, N. (1992) Microbiology: A Laboratory Manual (third ed). Benjamin/Cummings Pub.Co., New York, pp. 125-179.

Chaudhari, S.D., Naik V.R., Patel J.M., and Sodavadiya, H.B. (2017) Effect of Soil Conditioner and INM on Yield of Mungbean (Co: 4) Grown on Partially Reclaimed Coastal Salt Affected Soil of South Gujarat, India. Int J Curr.Microbiol.Appl.Sci. 6:2835-2840.

Chen, J., Lü, S., Zhang, Z., Zhao, X., Li, X., Ning, P., and Liu, M. (2018) Environmentally friendly fertilizers: A review of materials used and their effects on the environment. Sci Total Environ. 613: 829-839.

Cheng, Z., Park, E., and Glick, B.R. (2007) 1Aminocyclopropane-1-carboxylate deaminase from Pseudomonas putida UW4 facilitates the growth of canola in the presence of salt. Can. J. Microbiol.53:912-918.

Chet, I., and Chernin, L. (2002) Biocontrol, microbial agents in soil. Encyclopedia of environmental microbiology.

Dudeja, S.S., Giri, R., Saini, R., Suneja, P., and Kothe, E. (2012) Interaction of endophytic microbes with legumes. J. Basic Microbiol. 52: 248-260. 
Edi Premono, J., Moawad, A.M., and Vlek, P.L.G. (1996) Effect of phosphate solubilizing Pseudomonas putida on the growth of maize and its survival in the rhizosphere. Indones J. Crop Sci., 11: $13-23$.

Egamberdieva, D., Wirth, S., Behrendt, U., Ahmad, P., and Berg, G. (2017) Antimicrobial Activity of Medicinal Plants Correlates with the Proportion of Antagonistic Endophytes. Front Microbiol.8: 199-208.

Ezra, D., Hess, W.M., and Strobel, G.A. (2004) New endophytic isolates of Muscodoralbus, a volatile-antibioticproducing fungus. Microbiol.150:40234031.

Farooq M., Gogoi. N., Hussain M., barthakur S., Paul S., Bharadwaj N., Migdadi. H.M., Alghamdi S.S. andSiddique, K. H. M. (2017) Effects, tolerance mechanisms and management of salt stress in grain legumes. Plant Physiol.

Biochem., 118:199-217.

Fuganti-Pagliarini, R., Ferreira, L. C., Rodrigues, F. A., Molinari, H. B., Marin, S. R., Molinari, M. D., and Neumaier, N. (2017) Characterization of Soybean Genetically Modified for Drought Tolerance in Field Conditions. Front Plant Sci.8: 448.

Gordon, S.A. and Weber, R.P. (1951) Colorimetric estimation of indoleacetic acid. Plant Physiol. 26(1):192-195.

Grichko, V.P. and Glick, B.R. (2001) Amelioration of flooding stress by ACC deaminase-containing plant growthpromoting bacteria. Plant Physiol. Biochem., 39: 11-17.

Gtari, F.G., Hurst, S.G., Oshone, R., Morris, K., Abebe-Akele, F., Thomas, W.K., Ktari, A., Salem, K., Gtari, M. and Tisa, L. (2014) Draft genome sequence of Frankia sp. Strain BMG.23, a salt-tolerant nitrogen-fixing Actinobacterium isolated from the root nodule of Casuarina glauca grown in Tunisia. Genome Announc. 2(3): 520-14.
Hall, L., Doerr, K. A., Wohlfiel, S. L., and Roberts, G. D. (2003).Evaluation of the MicroSeq system for identification of mycobacteria by $16 \mathrm{~S}$ ribosomal DNA sequencing and its integration into a routine clinical mycobacteriology laboratory. J. Clin. Microbiol., 41(4): 1447-1453.

Li, X., Hu, B., Xu, Z., and Mew, T. (2008) Threshold population sizes of Bacillus Subtilis B5423-R to suppress the occurrence of rice sheath blight. Chin $\mathrm{J}$ Rice Sci. 17(4): 360-364.

Marsudi, N.D.S., Glenn, A.R. and Dilworth, M.J. (1999) Identification and characterization of fast and slow growing root nodule bacteria from South-Western Australian soils able to nodulate Acacia saligna. Soil Biol. Biochem., 31: 12291238 .

Matsuoka, H., Akiyama, M., Kobayashi, K. and Yamaji, K. (2013) Fe and P solubilization under limiting conditions by bacteria isolated from carex kobomugi roots at the Hasaki coast. Curr. Microbiol., 66(3): 314-321.

Mayak, S., Tirosh, T. and Glick, B.R. (2004) Plant growth-promoting bacteria that confer resistance to water stress in tomatoes and peppers. Plant Sci1 66(2): 525-530.

Narula, S., Anand, R.C. and Dudeja, S.S. (2013). Beneficial traits of endophytic bacteria from field pea nodules and plant growth promotion of field pea. J Food Legume. 26: 73-79.

Ngoma, L., Mogatlanyane, K. and Babalola, O.O. (2014) Screening of endophytic bacteria towards the development of cottage industry. In: An in Vitro Study. J Hum Ecol. 47(1):45-63.

Panchal, H. and Ingle, S. (2011) Isolation and characterization of endophytes from the root of medicinal plant Chlorophytum borivilianum (Safedmusli). J AdvDev Res.2: 205-209.

Penrose, D.M. and Glick, B.R. (2003) Methods for isolating and characterizing ACC deaminase-containing plant growth 
promoting rhizobacteria. Plant Physiol. 118(1):10-15.

Perez-Rosales, E., Alcaraz-Meléndez, L, and Puente, M.E. (2017) Isolation and characterization of endophytic bacteria associated with roots of jojoba (Simmondsia chinensis). CurrSci 112(2): 15-27.

Pikovskaya., R.I. (1948) Mobilization of phosphorus in soil in connection with the vital activity of some microbial species. Mikrobiologya. 17:362-370.

Rajendran, G., Patel, M.H. and Joshi, S.J. (2011) Isolation and characterization of nodule-associated Exiguo bacterium sp. from the root nodules of fenugreek (Trigonella foenum-graecum) and their possible role in plant growth promotion. Int J Microbiol. 2012: 1-8.

Rajkumar, M., Ae, N., Prasad, M.N.V. and Freitas, H., (2010) Potential of siderophore-producing bacteria for improving heavy metal phyto extraction. Trends Biotechnol.28: 142-149.

Rashid, S., Charles, T.C. and Glick, B.R. (2012) Isolation and characterization of new plant growth-promoting bacterial endophytes. Agric Ecosyst Environ. 61: 217-224.

Roy, S.J., Negrão, S., and Tester, M. (2014) Salt resistant crop plants. Curr. Opin. Biotechnol., 26: 115-124.

Saini, R., Kumar, V., Dudeja, S.S. and Pathak, D.V. (2015) Beneficial Effects of Inoculation of Endophytic Bacterial Isolates from Roots and Nodules in Chickpea. Int J Curr. Microbiol. Appl. Sci. 4(10): 207-221.
Schwyn, B. and Neilands, J.B. (1987) Universal chemical assay for the detection and determination of siderophores.Anal.Biochem.160: 47-56.

Selb, R., Wal, J. M., Moreno, F. J., Lovik, M., Mills, C., Hoffmann-Sommergruber, K., and Fernandez, A. (2017) Assessment of endogenous allergenicity of genetically modified plants exemplified by soybeanWhere do we stand? Food ChemToxicol.101: 138-149.

Singh D.P. and Singh B.B. (2011) Breeding for tolerance to abiotic stresses in mungbean. J Food Legumes. 24(2): 83-90.

Singh, R.P. and Jha, P.N. (2015) Plant Growthpromotingpotential of ACC deaminase rhizospheric bacteria isolated from aerva javanica: A plant adapted to saline environments. Int J Curr.Microbiol.Appl Sci. 4(7): 142-152.

Walkelin, S., Warren. R., Harvey, P. and Ryder, M. (2004) Phosphate solubilization by Penicillium spp. closely associated with wheat roots. BiolFertil Soils.40: 36-43.

Watanabe, H., Inaba, Y., Kimura, K., Asahara, S. and Kido, Y.et al., (2017) Dietary Mung Bean Protein Reduces Hepatic Steatosis, Fibrosis, and Inflammation in Male Mice with Diet-Induced, Nonalcoholic Fatty Liver Disease. J Nutr. 147(1):52-60.

Zhu, L., Bloomfield, K.J., Hocart, C.H., Egerton, J.J., O'Sullivan, O.S., Penillard, A. et al., (2018) Plasticity of photosynthetic heat tolerance in plants adapted to thermally contrasting biomes. Plant Cell Environ.

\section{How to cite this article:}

Rekha Sansanwal, Umang Ahlawat, Priyanka Batra and Leela Wati. 2018. Isolation and Evaluation of Multi-Trait Novel Bacterial Endophytes from Root Nodules of Mungbean (Vigna radiata). Int.J.Curr.Microbiol.App.Sci. 7(03): 2424-2430.

doi: https://doi.org/10.20546/ijcmas.2018.703.282 